\title{
Cell Dynamics in the Adult Mouse Olfactory Epithelium: A Quantitative Autoradiographic Study
}

\author{
A. Mackay-Sim ${ }^{1}$ and P. Kittel ${ }^{2}$ \\ 1Division of Science and Technology, Griffith University, Nathan, Queensland 4111, Australia and 2Department of \\ Physiology, University of Adelaide, Adelaide, South Australia 5000, Australia
}

The dynamics of cell genesis in the olfactory epithelium of the adult mouse were investigated using ${ }^{3} \mathrm{H}$-thymidine autoradiography. Mice were injected once with ${ }^{3} \mathrm{H}$-thymidine, and their olfactory epithelia were examined $7,14,30,60$, and $\mathbf{9 0} \mathrm{d}$ later. The number of silver grains over each nucleus was counted, and the relative distance from the basement membrane was measured for each labeled nucleus. At 7 and $14 \mathrm{~d}$, the average number of labeled cells in each section was about 20 per $\mathrm{mm}$. By $30 \mathrm{~d}$, and for the following $60 \mathrm{~d}$, the average number of labeled cells was only about 6 per $\mathrm{mm}$. Thus, most cells labeled by the injection died 2-4 weeks after injection. When the labeled cells were compared by nuclear grain density, time after injection (the "survival period"), and distance of the nucleus from the basement membrane (the "migration distance"), it was apparent that there was a small population of "nonmigrating" cells that remained close to the basement membrane. These cells, at first heavily labeled, divided a second time about $60 \mathrm{~d}$ after the ${ }^{3} \mathrm{H}$-thymidine injection, indicated by a significant decrease in nuclear grain density. This nonmigrating, slowly dividing basal cell is probably the neural stem cell, which gives rise to another stem cell and an olfactory neuron precursor by an asymmetric division. When the relative numbers of nonmigrating and migrating cells were compared, the results indicated that, after the asymmetric division, there are at least 2 or 3 rapid, symmetric divisions of the precursor cells, producing many immature receptor cells. Most of these die within 4 weeks of the ${ }^{3} \mathrm{H}$-thymidine injection. The results illustrate that olfactory neurogenesis is a heterogeneous process involving 2 classes of mitotically active basal cells with different rates of division and with different progeny. In many ways, neurogenesis in the adult olfactory epithelium mimics ontogenic processes common in the developing nervous system.

\footnotetext{
Received May 16, 1990; revised Nov. 13, 1990; accepted Nov. 19, 1990.

This work was supported in part by a grant from the National Health and Medical Research Council of Australia. We wish to thank Ms. Leeann Marsh for technical assistance during the course of these experiments.

Correspondence should be addressed to Dr. Alan Mackay-Sim, Division of Science and Technology Department, Griffith University, Nathan, QLD 4111, Australia.

Correspondence should be addressed to Dr. Alan Mackay-Sim, \% Dr. S. Roper Department of Neurobiology and Neuroanatomy, Colorado State University, Fort Collins, CO 80523 (before June 30, 1991) and to Dr. Alan Mackay-Sim at the above address (after June 30, 1991).
}

Copyright (C) 1991 Society for Neuroscience $0270-6474 / 91 / 110979-06 \$ 03.00 / 0$
Within the olfactory epithelium lies a unique stem cell that can give rise to new neurons throughout adult life. This gives the olfactory epithelium of the adult the capacity to replace the olfactory receptor neurons after damage to the olfactory nerve (Nagahara, 1940; Smith, 1951; Schultz, 1960; Westerman and von Baumgarten, 1964; Graziadei and DeHan, 1973; Matulionis, 1975; Graziadei and Monti Graziadei, 1979). In the undisturbed epithelium, there is considerable cell division in the basal cell layer evident from studies using ${ }^{3} \mathrm{H}$-thymidine autoradiography and from the mitoses that are observed close to the basement membrane (Moulton et al., 1970; Graziadei and Metcalf, 1971; Graziadei and Monti Graziadei, 1979; Hinds et al., 1984). Mitotically active cells are interspersed with nuclei whose features suggest that the progeny differentiate into receptor neurons. Morphologically, the basal cells are a mixed population of dark and light (or "globose") cells, the latter being assumed to be the receptor neuron precursor (Andres, 1966; Graziadei and Metcalf, 1971; Graziadei and Monti Graziadei, 1978, 1979; Rehn et al., 1981). Given the apparently continuous basal cell division and the presence of transitional nuclear types, the suggestion was made that there is a regular turnover of the receptor neurons (Moulton et al., 1970; Graziadei and Metcalf, 1971; Moulton and Fink, 1972; Graziadei, 1973; Moulton, 1974; Graziadei and Monti Graziadei, 1978, 1979). This vicw was challenged recently by Hinds et al. (1984), who suggested that this same evidence can be interpreted as turnover of immature, rather than mature, receptor neurons, and there is now evidence that the receptor neurons can live for at least 3 and even 12 months (Hinds et al., 1984; Mackay-Sim and Kittel, 1991).

With the constant addition of new cells to the olfactory epithelium, there must be a matched and constant loss of cells if the epithelium is not growing. There is no evidence for epithelial growth in adult mice through an expansion either in thickness or in surface area. In the mouse, the olfactory epithelium on the nasal septum has ceased expanding in surface area by 3 months of age (Hinds et al., 1984), and measurements of epithelial thickness in this region in adult mice show only small variation (Mackay-Sim and Beard, 1987). This suggests that cell birth and cell death must be under reciprocal homeostatic control. This notion is supported by evidence that loss of receptor neurons after chemical or mechanical insult stimulates basal cell division (Camara and Harding, 1984; Graziadei and Monti Graziadei, 1979; Rehn et al., 1981) and that epithelial thickness returns to normal after receptor cell damage (Matulionis, 1975; Graziadei and Monti Graziadei, 1979; Rehn et al., 1981).

In attempting to understand the control of this dynamic equi- 
librium, more knowledge of basal cell division in the undisturbed epithelium is required. For example, if the generative process is to be maintained throughout adult life, there must be a population of quiescent stem cells that provide a source for the neural precursors, as suggested by experiments in vitro (Calof and Chikaraishi, 1989). From these experiments, it was concluded that basal cell division may be a heterogeneous process involving cells with different rates of division and different progeny. It follows that estimates of cell turnover rates in vivo, which assume a homogeneous process, may be in error (e.g., Graziadei, 1973; Moulton and Fink, 1972; Moulton, 1974; Graziadei and Monti Graziadei, 1979).

The presence of a population of quiescent basal stem cells should be revealed by longitudinal ${ }^{3} \mathrm{H}$-thymidine studies, but evidence from such studies is equivocal. Some authors claim significant numbers of labeled basal cells for periods of up to 3 months after ${ }^{3} \mathrm{H}$-thymidine injection (Moulton et al., 1970), whereas others could find no labeled cells of any type after 30 d (Graziadei and Monti Graziadei, 1979). The latter finding could be explained if the rate of division of the stem cells was high enough to dilute the label to below background within 30 $\mathrm{d}$, though a high mitotic rate would seem counter to the function of a quiescent stem cell. All previous ${ }^{3} \mathrm{H}$-thymidine studies do agree, however, that most of the progeny of basal cell division migrate into the receptor cell layer of the epithelium and die within $30 \mathrm{~d}$ of injection (Moulton et al., 1970; Graziadei and Monti Graziadei, 1979; Hinds et al., 1984).

The aim of the present study was to reexamine the dynamics of basal cell division in the olfactory epithelium of the adult mouse. At different times after injection of ${ }^{3} \mathrm{H}$-thymidine, labeled cells were identified autoradiographically, their relative position in the epithelium was measured, and the number of silver grains over each nucleus was counted.

\section{Materials and Methods}

Adult, male, outbred albino Swiss mice, bred at Adelaide University Animal House and aged 12 weeks, were used in these experiments. They were housed under $12 \mathrm{hr}$ light daily, with lights on at 07:00 hr.

Fifteen mice were injected with ${ }^{3} \mathrm{H}$-thymidine (Amersham; specific activity, $77 \mathrm{Ci} / \mathrm{mmol} ; 5 \mu \mathrm{Ci} / \mathrm{gm}$ body weight, i.p.) between $10: 00$ and $12: 00 \mathrm{hr}$ on day 0 . After 7, 14,30,60, and $90 \mathrm{~d}$ (the "survival period"), between 10:00 and 12:00 hr, 3 mice were chosen at random from the group and deeply anesthetized with Nembutal, then decapitated. The heads were quickly dissected free of skin and muscle and immersed in fixative ( $4 \%$ paraformaldehyde, $5 \%$ glutaraldehyde, $\mathrm{pH} 7.2$, in $0.067 \mathrm{M}$ cacodylate buffer) for $24 \mathrm{hr}$. Prior to immersion, fixative was gently injected into the nasal cavity to expel any air bubbles. The heads were then decalcified for $24 \mathrm{hr}$ ( $10 \%$ formic acid in formalin), left overnight in $0.1 \mathrm{~m}$ sodium cacodylate $(\mathrm{pH}, 7.2)$, dehydrated, and embedded in glycol methacrylate.

Horizontal sections $2 \mu \mathrm{m}$ thick were cut, and every tenth section was mounted. In order to control for variations in epithelial thickness within the nasal cavity (Costanzo and Graziadei, 1983; Hinds et al., 1984), analysis was restricted to sections that were close to $1.5 \mathrm{~mm}$ ventral from the dorsal surface of the skull, and further restricted to the most caudal end of the nasal septum, as described previously (Mackay-Sim and Beard, 1987).

Sections chosen for analysis were dipped in Ilford K2 nuclear emulsion and processed in the standard manner for autoradiography. After 4-6 weeks exposure at $4^{\circ} \mathrm{C}$, these were developed and stained lightly with azure II and methylene blue.

Three sections, separated from each other by at least $50 \mu \mathrm{m}$, were chosen from each animal. On these, two sets of data were obtained. First, all the cells whose nuclei were labeled by at least 4 silver grains were counted along a $1-\mathrm{mm}$ length of nasal septum. No attempt was made to classify these cells into different cell types. The cell counts therefore included labeled supporting cells, but, by a previous estimate,
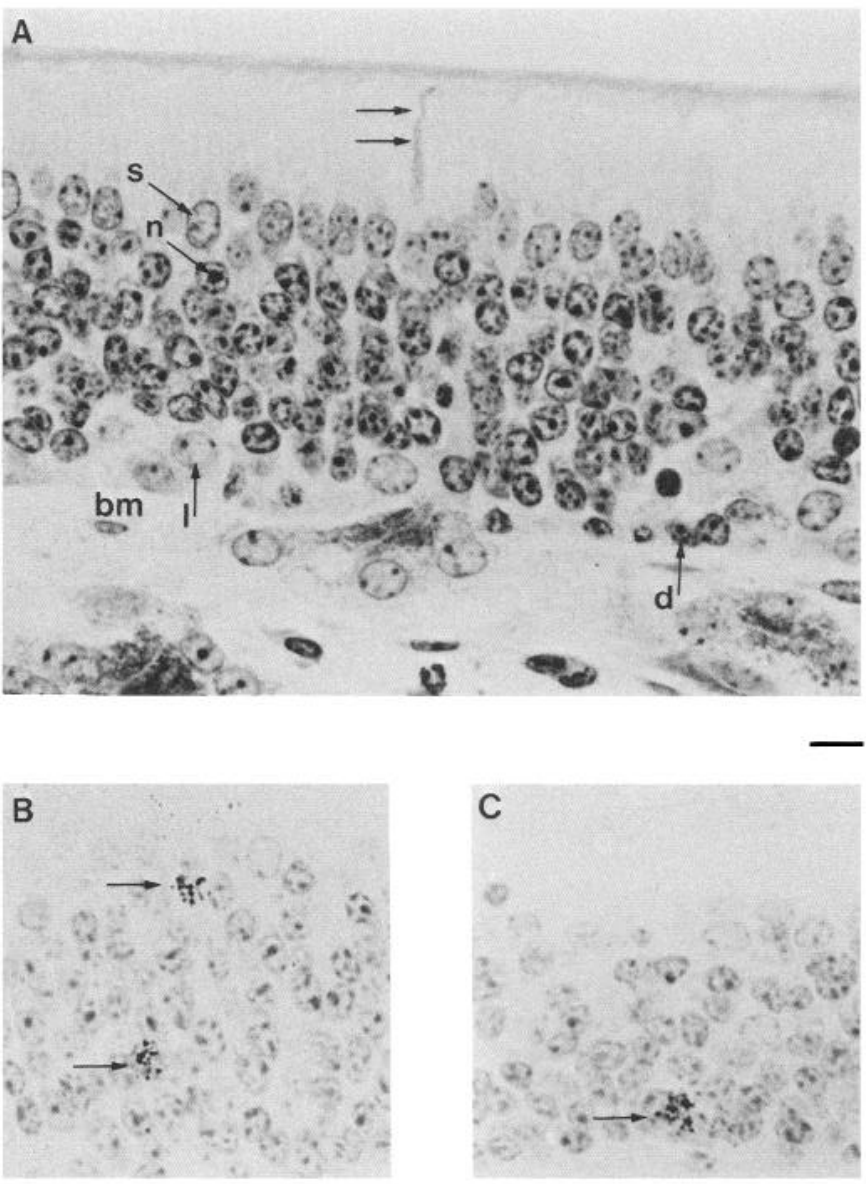

Figure 1. Labeled nuclei were observed $90 \mathrm{~d}$ after ${ }^{3} \mathrm{H}$-thymidine injection. $A$, Transverse section through the olfactory epithelium stained with toluidine blue. Supporting cell nuclei $(s)$ lie closest to the epithelial surface. Below these is the layer of nuclei of mature and immature receptor neurons $(n)$. Close to the basement membrane ( $b m$, unstained) lie the light $(l)$ and dark $(d)$ basal cells. Below the basement membrane can be seen the Bowman's glands, whose ducts run to the epithelial surface (double arrows). $B$ and $C$, Photomicrographs of nuclei labeled with silver grains $90 \mathrm{~d}$ after injection (arrows), within the receptor nuclei layer $(B)$ and close to the basement membrane $(C)$. Scale bar, $10 \mu \mathrm{m}$ for $A-C$.

these constitute fewer than 1 in 16 labeled cells (Mackay-Sim and Beard, 1987). Second, in the same sections, a more extensive analysis was performed: the number of silver grains over each nucleus was counted, the distance of the center of the nucleus from the basement membrane was measured, and the epithelial thickness from basement membrane to the luminal surface at the position of each labeled nucleus was measured. From the latter two measurements, the distance from the basement membrane was expressed as a percentage of the epithelial thickness. This gave a relative "migration distance." In order to increase the number of cells in the second analysis, measurements were made from $3 \mathrm{~mm}$ of septal epithelium for each animal, except in the 60-d group, where technical problems in one animal restricted the analysis to $1 \mathrm{~mm}$. Because it was considered statistically prudent to have equal contributions from all animals in each group, the analysis of the other two animals in the 60-d group was restricted to $1 \mathrm{~mm}$.

All measurements were made with a computer-assisted microscopy technique (Halasz and Martin, 1984) at a magnification of $1250 \times$ under oil immersion. All measurements were made with the observer unaware of the animal from which the section was taken.

Cell counts and measurements throughout are given as mean \pm SEM and represent analyses of 3 sections from 3 animals per treatment. None of the measurements were corrected for shrinkage during the histological procedures, but this should be the same for all tissues because they were 


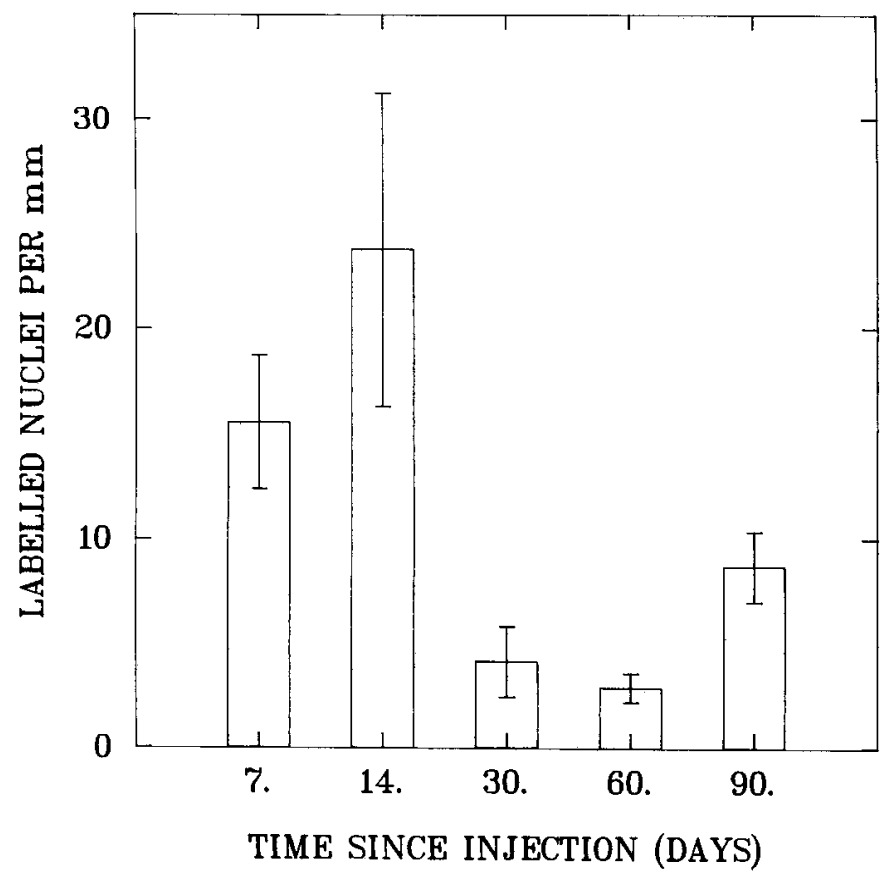

Figure 2. The numbers of labeled nuclei varied with the time since ${ }^{3} \mathrm{H}$-thymidine injection. This graph shows the mean numbers $( \pm \mathrm{SEM})$ of labeled nuclei per millimeter of olfactory epithelium on the nasal septum at different times after injection.

treated similarly. None of the animals showed any evidence of rhinitis or other nasal infections.

The frequencies of labeled nuclei at different time periods were compared with a $\chi^{2}$ test. Migration distances and nuclear grain densities were compared by analysis of variance.

\section{Results}

Survival of nuclei labeled with ${ }^{3} \mathrm{H}$-thymidine

There were labeled nuclei at all periods up to $90 \mathrm{~d}$ after injection (Figs. 1, 2). The number of labeled cells was biphasic, with a significant decrease in the number of labeled nuclei after $14 \mathrm{~d}$. (The mean number of nuclei up to $14 \mathrm{~d}$ was $19.7 \pm 4.1$ per $\mathrm{mm}$, and after $14 \mathrm{~d}$ was $5.9 \pm 0.9$ per $\mathrm{mm}$ of nasal septum.) A $\chi^{2}$ test on these data indicated a significant difference among the survival periods $\left(\chi^{2}=247.7 ; \mathrm{df}=4 ; p<0.001\right)$. Thus, though significantly reduced in number after $14 \mathrm{~d}$, labeled nuclei were observed at all survival periods, including $90 \mathrm{~d}$ postinjection. There was no significant difference between the number of labeled cells at 7 and $14 \mathrm{~d}$ or among any of the survival periods after $14 \mathrm{~d}$.

\section{Density of ${ }^{3} \mathrm{H}$-thymidine labeling}

Overall, there was no apparent correlation between survival period and grain density. At all survival periods, the number of silver grains per nucleus varied greatly (Fig. 3). When all the data were pooled, there was also no obvious relation between the nuclear grain density and the relative distance from the basement membrane (Fig. 4).

\section{Comparison of lightly versus heavily labeled cells}

Cells were classified into three groups according to the number of silver grains per nucleus: "lightly labeled," cells with fewer than 10 grains per nucleus; "heavily labeled," cells with more than 25 grains per nucleus; and "midrange," cells with a nuclear

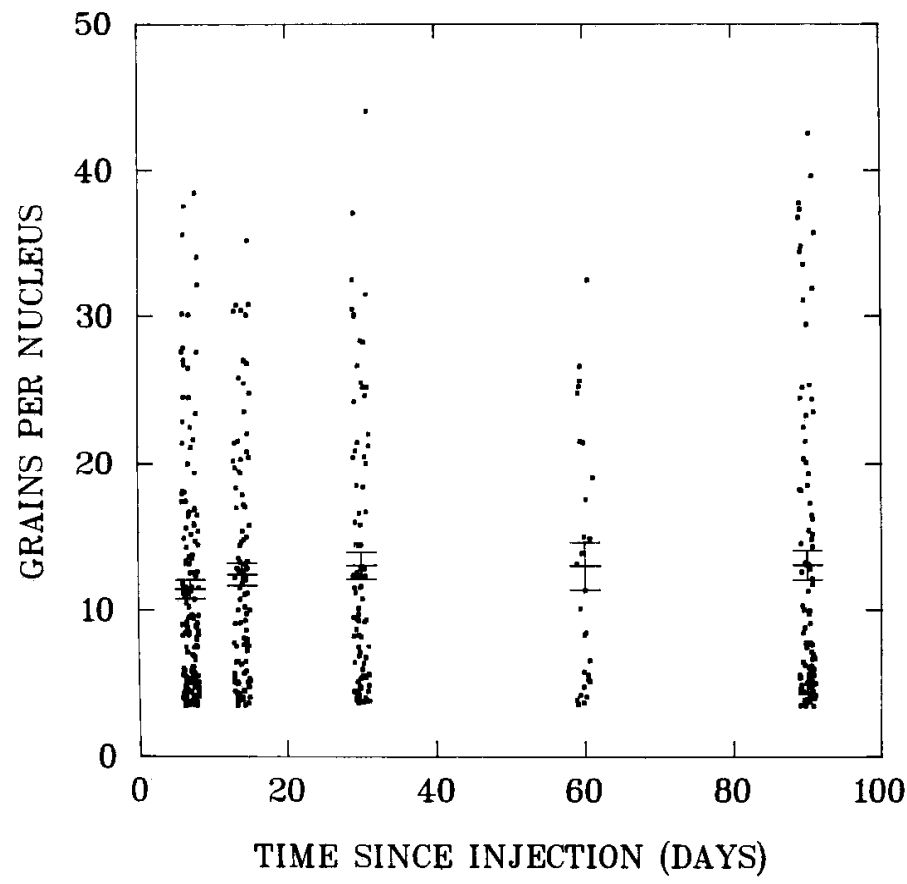

Figure 3. The density of silver grains per nucleus varied with survival period. This graph shows nuclear grain density as a function of the time since injection of ${ }^{3} \mathrm{H}$-thymidine. Bars show the mean $( \pm$ SEM) for each survival period.

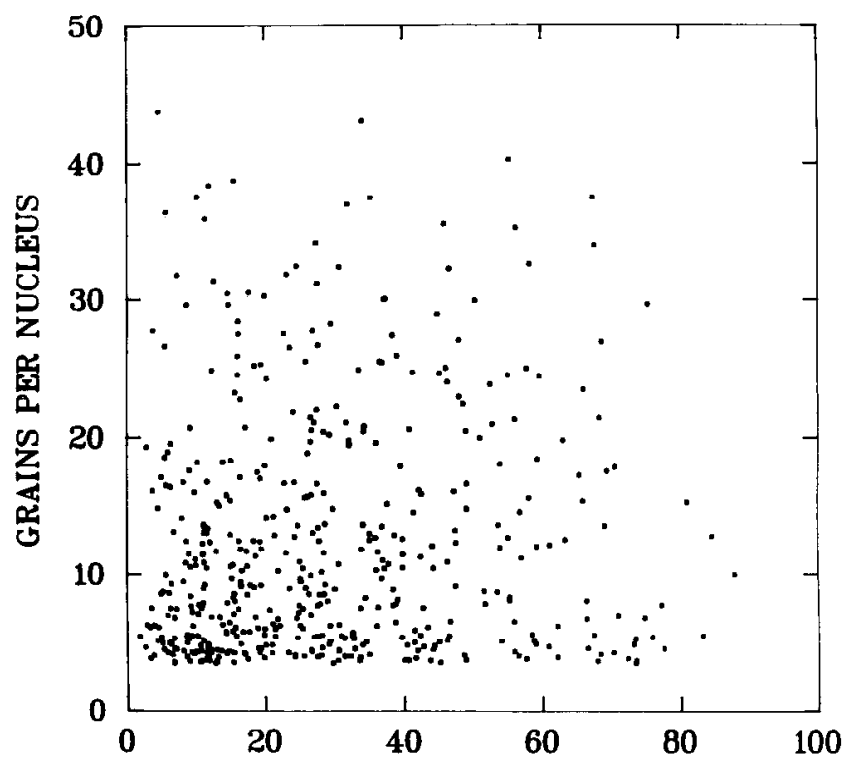

RELATIVE DISTANCE FROM BASEMENT MEMBRANE

Figure 4. The density of silver grains per nucleus varied with migration distance. This graph shows nuclear grain density as a function of the relative distance of each nucleus from the basement membrane, where $0 \%$ would be on the basement membrane and $100 \%$ would be at the epithelial surface.

grain density between these two extremes. When these cell classes were compared by migration distance and survival period, there is a clear divergence of the lightly labeled class at $60 \mathrm{~d}$ survival (Fig. 5). ANOVA on these data indicated significant differences among the survival periods $\left(F_{4.455}=32.15 ; p<0.001\right)$ and among the cell classes $\left(F_{2,45 s}=6.66 ; p=0.002\right)$ and a significant interaction between survival period and cell type $\left(F_{8,455}=2.56 ; p=0.01\right)$ 


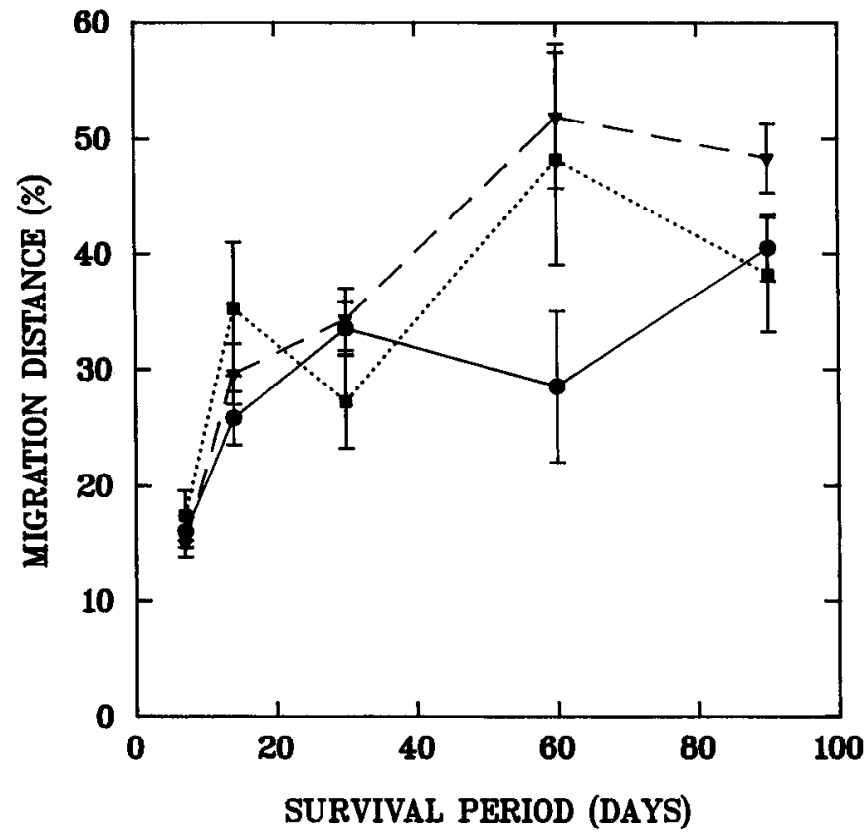

Figure 5. Comparison of migration distances of nuclei with different grain densities. This graph shows mean migration distance $( \pm$ SEM) among cells classified according to the number of silver grains per nucleus. The squares represent "heavily labeled" cells, with more than 25 grains per nucleus. The circles represent "lightly labeled" cells, with fewer than 10 grains per nucleus. The triangles represent "midrange" cells, with nuclear grain densities between these limits.

\section{Comparison of basal cells with other cells}

Another way to approach the data is to compare the nuclear grain density of basal cells with other cell types. Because identifying these cells with light microscopy is problematic, cells were classified as "basal" if their nuclei were located within $10 \%$ of the distance from the basement membrane to the luminal surface (i.e., those with a migration distance of less than $10 \%$ ). Thc mcan cpithelial thickness was $64.2 \pm 3.1 \mu \mathrm{m}$, and the mean diameter of cells in the basal cell compartment was $5.7 \pm 0.04$ $\mu \mathrm{m}$ ( $n=162$, corrected for section thickness; Weibel, 1980). Therefore, the only cells classed as "basal" were those whose centers lay within one nuclear diameter of the basement membrane.

The grain density of basal cells varied considerably at different survival periods compared to all other cells (Fig. 6). ANOVA on these data indicated a significant interaction between cell type and survival period $\left(F_{4,460}=2.45 ; p<0.045\right)$. Although the "other" cells showed no difference in grain density at different survival periods, the basal cells showed a biphasic variation with grain density rising to a peak at $30 \mathrm{~d}$ survival and dropping to $1 / 3$ of this value at 60 and $90 \mathrm{~d}$ (Fig. 6). The numbers of labeled basal cells at $7,14,30,60$, and $90 \mathrm{~d}$ were $53,7,5$, 5 , and 6 , respectively. The numbers of other cells were 101, 94, 84,23 , and 92 , respectively. Therefore, basal cells comprised $33.9 \%, 5.4 \%, 5.6 \%, 17.9 \%$, and $6.0 \%$ of all labeled cells at the respective survival periods.

\section{Discussion}

\section{Receptor neuron replacement}

In agreement with all previous studies, the results show that most of the cells labeled by an injection of ${ }^{3} \mathrm{H}$-thymidine disappear from the epithelium between 14 and $30 \mathrm{~d}$ postinjection

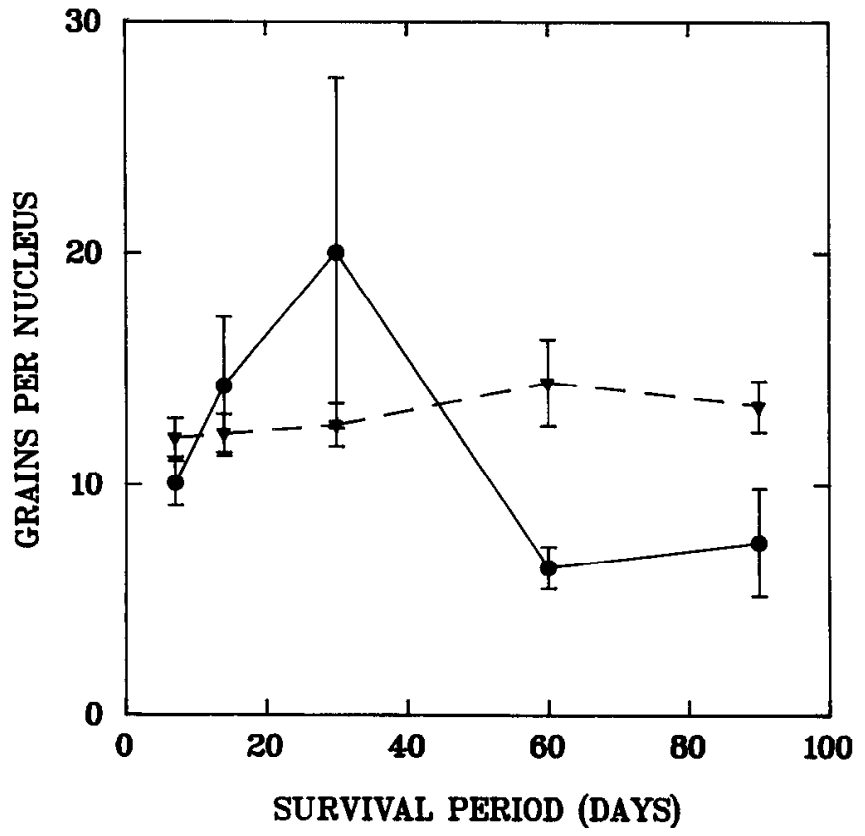

Figure 6. Comparison of nuclear grain densities of basal cells (nuclei with a migration distance of less than $10 \%$ ) with all other cells at different survival periods. This graph shows mean nuclear grain density $( \pm \mathrm{SEM})$. The circles represent basal cells. The triangles represent all other cells.

(Moulton et al., 1970; Graziadei and Monti Graziadei, 1979; Hinds et al., 1984). A few cells, however, remained in the epithelium for up to $90 \mathrm{~d}$ postinjection (Figs. 1, 2). Some of these probably represent receptor neurons that have matured and survived from a mitosis at the time of ${ }^{3} \mathrm{H}$-thymidine injection. This conclusion is based on the observation that some heavily labeled cells were present in the receptor cell compartment at $90 \mathrm{~d}$ (Fig. 5). Only heavily labeled cells can be unequivocally identified as those resulting from a single division at the time of ${ }^{3} \mathrm{H}$-thymidine injection. Other labeled cells with fewer silver grains could arise from basal cell divisions subsequent to injection. Without microscopic evidence of the identity of these cells, however, this can only be regarded as indirect evidence for receptor neuron replacement. Nevertheless, it corroborates the study of Hinds et al. (1984), who verified the identity of the labeled cells under the electron microscope.

\section{Basal stem cell cycle}

The results provide evidence for two phases of basal cell division: a slow phase and a rapid phase. In the slow phase, the stem cell divides about every $60 \mathrm{~d}$. There is first an asymmetric division giving rise to a new stem cell, which remains in the slow phase, and a daughter cell, which enters the rapid phase. The rapid phase is a period of multiple symmetric divisions, the final progeny of which are immature receptor cells that migrate away from the basement membrane.

Because much of the following discussion rests on the interpretation of the density of silver grains over labeled nuclei, some consideration should be given to the factors that lead to the high degree of variability in nuclear grain density (Figs. 3, 4). This variability arises, in part, for "technical" reasons such as the range in sizes of nuclear fragments within each $2-\mu \mathrm{m}$-thick section, the range in the stage of DNA synthesis of different cells at the time of ${ }^{3} \mathrm{H}$-thymidine injection, and the relative distance of the nucleus from the overlying emulsion. For example, a cell 
at the beginning of DNA synthesis at the time of injection may have the largest possible amount of ${ }^{3} \mathrm{H}$-thymidine in its nucleus, but if only a fragment of the nucleus is present in the section, it may only expose a few silver grains in the emulsion. Such sources of variability in nuclear grain density will occur randomly with respect to experimental variables, and their influence will tend to obscure any nonrandom variability present. Other sources of variability were minimized by processing all sections at the same time, with the same emulsion and with the same exposure and development times.

There is one nonrandom source of variability that could consistently reduce the mean nuclear grain density at increasing survival periods, namely, cell division, which would dilute the label by half at each mitosis. Because mitosis occurs close to the basement membrane, the more lightly labeled progeny of recent divisions at any survival period would not have migrated as far as cells labeled at an earlier division. Evidence for this is shown in Figure 6, in which the basal cells at 60 and $90 \mathrm{~d}$ had about $50 \%$ of the nuclear grain density of all other cells at those survival periods. Despite the inherent variability in the data, this difference was statistically different. This indicates that the basal cells underwent a second division between 30 and $60 \mathrm{~d}$. In addition, Figure 5 shows a group of lightly labeled cells that are closer to the basement membrane than all the other cells. Considering that basal cell mitosis is only one factor that can reduce nuclear grain density, these data strongly support the proposal that there is a second phase of basal cell mitosis between 30 and $60 \mathrm{~d}$. We refer to this phase as the "slow phase."

Slow-phase cells undergoing DNA synthesis at the time of injection would generate a nonmigrating stem cell, which would be identified as heavily labeled, because a high grain density unequivocally represents only one mitosis. After the progeny migrated away from the basement membrane, the nonmigrating stem cells would remain. Any subsequent divisions of the nonmigrating stem cells would generate a new population of labeled cells with about half the grain density of cells labeled at the first division. This new population of basal cells was first seen at 60 $\mathrm{d}$ and was still present at $90 \mathrm{~d}$ (Fig. 6).

Evidence for a "rapid phase" of basal cell division is provided by the large number of labeled cells at 7 and $14 \mathrm{~d}$ (Fig. 2). By $14 \mathrm{~d}$, most of these cells had migrated away from the basement membrane. Multiple divisions during the rapid phase would dilute the label, so that the migrating cells should have, on average, relatively fewer silver grains per nucleus compared to the nonmigrating cells, as observed (Fig. 6, days 7-30). At 60 $\mathrm{d}$, just following the second phase of stem cell division, there was another increase in lightly labcled cells close to the basement membrane (Fig. 5), as expected of a second phase of rapid cell division. By $90 \mathrm{~d}$, the surviving progeny of the second phase of division were indistinguishable from those of the first phase (Fig. 5). These conclusions are also supported by the relative numbers of labeled cells that were classified as "basal" at different survival periods. At 14, 30, and $90 \mathrm{~d}$, basal cells represented $5.4 \%, 5.6 \%$, and $6.0 \%$ of all labeled cells at each respective period. Conversely, at 7 and $60 \mathrm{~d}$, "basal" cells represented $33.9 \%$ and $17.9 \%$ of labeled cells. By extrapolation from the first cell division, the presence of this relatively large proportion of labeled "basal" cells at $60 \mathrm{~d}$ indicates that a second phase of symmetric cell division and migration was occurring at about that time.

That these symmetric divisions are "rapid" is suggested by the fact that maximum numbers of labeled nuclei were achieved by $7 \mathrm{~d}$. The divisions may be completed earlier than this because we have previously found similar numbers of labeled cells (1520 per $\mathrm{mm}$ of nasal septum) at 1,5 , and $15 \mathrm{~d}$ after ${ }^{3} \mathrm{H}$-thymidine injection in our control groups in other experiments (MackaySim and Beard, 1987; Mackay-Sim and Dreosti, 1989). Other workers have found a maximum number of labeled cells $1 \mathrm{~d}$ after injection of ${ }^{3} \mathrm{H}$-thymidine (Moulton et al., 1970; Hinds et al., 1984).

It is possible from the results to estimate at least a lower limit to the number of symmetric divisions in the rapid phase. At 14 $\mathrm{d}$, before the death of most of the migrating cells, these cells outnumbered the nonmigrating cells by about 17 to 1 . This ratio suggests that the rapid phase represents 2 or 3 successive, symmetric divisions giving rise to the migrating cells. For example, asymmetric division of 1 stem cell followed by 2 symmetric divisions would generate 1 stem cell plus 4 immature receptor neurons. The total number of labeled cells, however, would be 12 immature receptor neurons plus 1 basal stem cell because cell division would be occurring simultaneously at all 3 levels of the hierarchy. Dividing cells at any level of this hierarchy would incorporate ${ }^{3} \mathrm{H}$-thymidine and, except for the daughter stem cell, would progress to the terminal stage. Three, rather than 2 , symmetric divisions would generate 8 immature receptor neurons for each stem cell, but with DNA synthesis occurring simultaneously in cells at 4 levels of the hierarchy, one would observe 32 labeled migrating cells for each labeled stem cell. This hierarchy of cell divisions would add further to the variability of the nuclear grain densities (Figs. 3, 4) because labeled cells could arise from any level. It is therefore difficult to determine exactly the number of symmetric divisions in the rapid phase, because these divisions may dilute the label by at least 2- or 3-fold, reducing nuclear grain density to below the 4 grains used to define a "labeled" cell. For example, if the maximum nuclear grain density observed was 40,3 divisions would reduce the density to 5 grains. Because maximal density is seen only in nuclei sectioned through the center, many progeny of a "40grain" cell would have less than 4 grains after 3 symmetric divisions. Only 3 cells in this study had as many as 40 grains, so it must be assumed that the number of labeled cells observed provides an underestimate of the number of cells involved. It is concluded, therefore, that the 17:1 ratio of migrating to nonmigrating cells at $14 \mathrm{~d}$ probably resulted from at least 2 or 3 symmetric divisions in the rapid phase.

Dilution of label through multiple rapid divisions explains why there is no difference in the mean nuclear grain density of the nonbasal cells between 60 and $90 \mathrm{~d}$ (Fig. 6). In this case, labeled cells would only arise from previously labeled basal stem cells. These represent only $6 \%$ of the cells labeled at $30 \mathrm{~d}$, and, assuming 1 asymmetric and 3 symmetric divisions, each would produce only 8 migrating cells. Because the average grain density at $30 \mathrm{~d}$ was 20 per basal cell (Fig. 6), most of the progeny would have fewer than 4 silver grains. Of these, only about $30 \%$ would survive until $90 \mathrm{~d}$, so these cells would contribute negligibly to the observed number of labeled cells at $90 \mathrm{~d}$. The apparent increase in labeled cells between 60 and $90 \mathrm{~d}$ (Fig. 2) was not statistically significant.

The present results therefore support a proposed model of olfactory neurogenesis in which basal stem cells "give rise to neurons by way of an intermediate cell type which divides as it migrates away from them"' (Calof and Chikaraishi, 1989). The stem cell on which this two-phase cycle of neurogenesis is dependent may be the dark basal cell because these cells are typ- 
ically located very close to the basement membrane, similar to the basal stem cells in the present study (Andres, 1966; Rehn et al., 1981). The more numerous globose basal cells are labeled very soon after ${ }^{3} \mathrm{H}$-thymidine injection (Graziadei and Monti Graziadei, 1979) and are probably those in the rapid phase of division. Indirect evidence for this was provided when the olfactory epithelium regenerated after chemical damage (Rehn et al., 1981). During the period of stimulated cell division, the numbers of the dark basal cells were reduced, and they appeared to be replaced by globose basal cells. Later, when receptor neuron replacement was complete, the dark basal cells were as common as before (Rehn et al., 1981).

\section{Olfactory neurogenesis in adult reflects ontogenesis}

The two phases of cell division observed in this study reflect two separate functions commonly associated with embryonic development of the nervous system, namely, de novo synthesis of new tissue (the slow phase) and expansion, or growth, of this tissue (the rapid phase). At least 2 other aspects of olfactory neurogenesis also reflect ontogenesis. First, the survival of progeny of the rapid phase of division is thyroxine dependent (Mackay-Sim and Beard, 1987). Sccond, during development of the nervous system, there is usually an overproduction of immature cells, followed by naturally occurring death of many of these if they fail to make the correct connections (for reviews, see Oppenheim, 1985; Williams and Herrup, 1988). During development, naturally occurring cell death can be quite extensive; for example, in the cat retina, $80 \%$ of retinal ganglion cells die during development (Williams et al., 1986). A similar phenomenon occurs in the olfactory epithelium, where most of the immature receptor cells, produced by the rapid phase of division, die 2-4 weeks after birth (Fig. 2; Hinds et al., 1984). Presumably, each cell passes through a period during which synaptic connections must be established (Hinds et al., 1984) and dendritic space must be found at the epithelial surface (Mackay-Sim et al., 1988). A few cells, possibly those achieving both these tasks, finally develop into mature receptor neurons. Neurons that successfully traverse the developmental period may, like other mature neurons, live for long periods (Hinds et al., 1984; Breipohl et al., 1986; Mackay-Sim and Kittel, 1991). Unlike most other neurons, however, olfactory receptor neurons are directly exposed to the environment and thereby open to damage from environmental factors such as disease or toxic chemicals (Rehn et al., 1981; Hinds et al., 1984; Breipohl et al., 1986; Farbman et al., 1988). Certainly, some of the heavily labeled, migrating cells in this study lived for 3 months (Figs. 2, 5). A life-span of at least this period was confirmed directly when receptor neurons were labeled retrogradely by injection of colloidal gold into the olfactory bulb (Mackay-Sim and Kittel, 1991).

\section{References}

Andres KH (1966) Der Feinbau der Regio olfactoria von Makrosmatikern. Z Zellforsch Mikrosk Anat 69:140-154.

Breipohl W, Mackay-Sim A, Grandt D, Rehn B, Darrelmann C (1986) Neurogenesis in the vertebrate main olfactory epithelium. In: Ontogeny of olfaction (Breipohl W, ed), pp 21-33. Berlin: Springer.

Calof AL, Chikaraishi DM (1989) Analysis of neurogenesis in a mammalian neuroepithelium: proliferation and differentiation of an olfactory neuron precursor in vitro. Neuron 3:115-127.

Camara CG, Harding JW (1984) Thymidine incorporation in the olfactory epithelium of mice: early exponential response induced by olfactory neurectomy. Brain Res 308:63-68.
Costanzo RM, Graziadei PPC (1983) A quantitative analysis of changes in the olfactory epithelium following bulbectomy in hamster. J Comp Neurol 215:370-381.

Farbman AI, Brunjes PC, Renfro L, Michas J, RitzS (1988) The cffect of unilateral naris occlusion on cell dynamics in the developing rat olfactory epithelium. J Neurosci 8:3290-3295.

Graziadei PPC (1973) Cell dynamics in the olfactory mucosa. Tissue Cell 5:1 13-131.

Graziadei PPC, DeHan RS (1973) Neuronal regeneration in frog olfactory epithelium. J Cell Biol 59:525-530.

Graziadei PPC, Metcalf JF (1971) Autoradiographic and ultrastructural observations on the frog's olfactory mucosa. Z Zellforsch Mikrosk Anat 116:305-318.

Graziadei PPC, Monti Graziadei GA (1978) Continuous nerve cell renewal in the olfactory system. In: Handbook of sensory physiology, Vol IX, Development of sensory systems (Jacobson $\mathbf{M}$, ed), pp 5583. Berlin: Springer.

Graziadei PPC, Monti Graziadei GA (1979) Neurogenesis and ncuron regeneration in the olfactory system of mammals. I. Morphological aspects of differentiation and structural organization of the olfactory sensory neurons. J Neurocytol 8:1-18.

Halasz P, Martin P (1984) A microcomputer based system for semiautomatic analysis of histological sections. Proc R Microse Soc 19:312P.

Hinds JW, Hinds PL, McNelly NA (1984) An autoradiographic study of the mouse olfactory epithelium: evidence for long-lived receptors. Anat Rec 210:375-383.

Mackay-Sim A, Beard MD (1987) Hypothyroidism disrupts neural development in the olfactory epithelium of adult mice. Dev Brain Res 36:190-198.

Mackay-Sim A, Dreosti I (1989) Olfactory function in zinc deficient adult mice. Exp Brain Res 76:207-212.

Mackay-Sim A, Kittel P (1991) On the life span of olfactory reccptor neurones. Eur $\mathbf{J}$ Neurosci, in press.

Mackay-Sim A, Breipohl W, Kremer M (1988) Cell dynamics in the olfactory epithelium of the tiger salamander: a morphometric analysis. Exp Brain Res 71:189-198.

Matulionis DH (1975) Ultrastructural study of mouse olfactory epithelium following destruction by $\mathrm{ZnSO}_{4}$ and its subsequent regeneration. Am J Anat 142:67-90.

Moulton DG (1974) Dynamics of cell populations in the olfactory epithelium. Ann NY Acad Sci 237:52-61.

Moulton DG, Fink RP (1972) Cell proliferation and migration in the olfactory epithelium. In: Olfaction and taste, Vol IV (Schneider D, ed), pp 20-26. Stuttgart: Wissenschaftliche Verlagsgesellschaft.

Moulton DG, Celebi G, Fink RP (1970) Olfaction in mammals-two aspccts: proliferation of cells in the olfactory epithelium and sensitivity to odours. In: Taste and smell in vertebrates (Wolstenholme GEW, Knight J, eds), pp 241-252. London: Churchill.

Nagahara Y (1940) Experimentelle Studien über die histologischen Veranderungen des Geruchsorgans nach der Olfactoriusdurchschneidung. Beitrage zur Kenntnis des feineren Baus der Geruchsorgans. Jpn J Med Sci Pathol 5:165-199.

Oppenheim RW (1985) Naturally occurring cell death during neural development. Trends Neurosci 8:487-493.

Rehn B, Breipohl W, Schmidt C, Schmidt U, Effenberger F (1981) Chemical blockade of olfactory perception by $N$-methyl-formiminomethylester in albino mice. II. Light microscopical investigations. Chem Senses 6:317-328.

Schultz EW (1960) Repair of the olfactory mucosa. Am J Pathol 37: $1-19$.

Smith CG (1951) Regeneration of sensory olfactory epithelium and nerves in adult frogs. Anat Rec 109:661-671.

Weibel ER (1980) Stereological methods, Vol II, Theoretical foundations. London: Academic.

Westerman RA, von Baumgarten R (1964) Regeneration of olfactory paths in carp. Experientia 20:519-520.

Williams RW, Herrup K (1988) The control of neuron number. Annu Rev Neurosci 11:423-453.

Williams RW, Bastiani MJ, Lia B, Chalupa LM (1986) Growth cones, dying axons, and developmental fluctuations in the fiber populations of the cat's optic nerve. J Comp Neurol 246:32-69. 